\title{
IMPROVING FRUIT QUALITY OF MANFALOTY AND WONDERFULL POMEGRANATES BY USING BAGGING AND SOME SPRAY TREATMENTS WITH GIBBERELLIC ACID, CALCIUM CHLORIDE AND KAOLIN. \\ Hegazi, A. ${ }^{1}$; N. R.Samra ${ }^{1}$;; E. E. T. El-Baz ${ }^{1}$.; Bahan. M.Khalil ${ }^{2}$ and M.S.Gawish ${ }^{2}$ \\ 1-Pomology Dept.,Fac.Agric.,Mansoura Univ.,Egypt. \\ 2- Hort. Res. Inst., ARC, Egypt
}

\begin{abstract}
This study was carried out during the two successive seasons of 2012 and 2013 on Manfaloty and Wonderful pomegranate trees at5 and 3-years old respectively, the trees were spaced at $4 \times 4 \mathrm{~m}$. grown in a sandy soil. The highest values of yield and its components i.e., fruit weight, fruit number/tree and yield /tree were recorded when Manfaloty and Wonderful pomegranate trees treated with $\mathrm{GA}_{3}$ at 50 or $100 \mathrm{ppm}, \mathrm{CaCl}_{2}$ $4 \%$, kaolin 2.5 or $5 \%$ and bagging treatment. The lowest percentage of fruit creaking and sunburn were obtained with bagging treatment followed by kaolin $5 \%$ and spraying by $\mathrm{CaCl}_{2}$ and $\mathrm{GA}_{3}$ treatments compared with the control treatment. All treatments caused a highly significant increase in Marketable fruits \%. Bagging treatment gave the highest Marketable fruits percentage compared with the control and other treatments. The highest fruit length and diameter obtained by $\mathrm{GA}_{3} 50$ or $100 \mathrm{ppm}$ and $\mathrm{CaCl}_{2} 2$ or $4 \%$ treatment. Furthermore, $\mathrm{GA}_{3}$, kaolin and bagging treatments improved SSC, total acidity and SSC/acid ratio ,meanwhile the highest anthocyanin content in juice and peel was obtained by bagging and spraying kaolin $5 \%$ treatments in both cultivars. Therefore, these treatments could be recommended for improving Manfaloty and Wonderfull pomegranate cvs performance under similar conditions of this study.
\end{abstract}

Keywords: Pomegranate, bagging, foliar spray, $\mathrm{GA}_{3}$, kaolin, $\mathrm{CaCl}_{2}$, fruit cracking, sunburn, fruit quality.

\section{INTRODUCTION}

Pomegranate (Punica granatum L.) is one of the oldest known edible fruits, among the fruit kinds mentioned in the Holy Quran and an important in human medicine and its components have a wide range of clinical applications (Lansky \& Newman, 2007). The cultivated area nowadays, acreage is rapidly increasing especially with Wonderfull cultivar under the new reclaimed lands. The total cultivated area is about 26351 feddans. From this area, the fruiting area was about 9746 feddans which produced about 89035 tons (Ministry of Agriculture statistics, 2012). Manfaloty and Wonderfull pomegranate are the most important cultivars in Egypt.

Fruit cracking is a serious problem in pomegranate which hinders its cultivation to a large extent. Cracking varies from 10 to $70 \%$ depending upon the prevailing environmental conditions. Various factors are responsible for fruit cracking which include fluctuation in soil moisture regimes, climate, tree nutrition and cultivars (Kumar et al., 2010).It may also occur due to micronutrient deficiency in young fruits, while in mature fruits it might be due 
to moisture imbalance or due to extreme variations in day and night temperatures (Abd El-Rhman, 2010). Cracked fruits lose their value for the fresh market and are used for processing only as fruit juice if not affected by fungi. Cracked fruits are susceptible to storage disease and have a shorter storage as well as shelf-life.

Pomegranates are especially sensitive to sunburn because they are terminal-bearing plants, with generally thin branches that bend with the increase in fruit weight as the season progresses (Melgarejo et al. ,2004 and Samra \& Shalan, 2013). This exposes fruit parts that had developed previously in the shade, and are extremely sensitive to sunburn. Pomegranates are picked in early autumn, therefore the fruits exposed to high temperatures throughout the summer. As a result, the incidence of sunburn damage can be high causing grower losses that may exceed $30 \%$ of the harvested fruits (Melgarejo \& Martinez, 1992) Controlling irrigation, bagging and spraying pomegranate with $\mathrm{GA}_{3}$ or kaolin reduced the percentage of fruit cracking ,sunburn (Talaat et al.,2009 and Abd ElRhman,2010) Gibberrellic acid is used widely in various horticultural crops for improving fruit set and also to control cracking of pomegranate fruit (Sepahi, 1986) and litchi (Sharma \& Dhillon, 1986) In addition, $\mathrm{GA}_{3}$ may be influencing cell wall strength or elasticity (Byers et al. 1990) The beneficial role of $\mathrm{Ca}$ in reducing fruit splitting might be attributed to owing as a cement material plays a vital role in increasing firmness of fruit which reduces water evaporation and increases withstand of the trees to water and drought stresses (Tuckey, 1986).

Kaolin has recently been utilized in the development of hydrophilic particle film technology. This technology uses chemically inter, non - toxic mineral particles coat to plant surfaces(Glenn et al. 1999). Kaolin application showed significantly positive effect on protection of fruit against sunburn on Fuji and Honeycrips apple cultivars (Schupp et al., 2002) These positive results on Kaolin application was also confirmed with studies of Melgarejo, et al., (2004), Abd El-Rhman, (2010) and Samra \& shalan (2013)on pomegranate and Glenn et al., 1999 on apple cultivars.

Fruit bagging is one of the most effective techniques to produce highquality, pollution-free fruits and got more attentions to the fruit producers during the recent decades were obvious. The quality of fruit bagging has been getting better and better. The effect of bagging on appearance quality (brightness, color, size and weight of single fruit), the quality of fruit contents such as total soluble solids, titrable acids, vitamin C, become more apparent procedure. Also, the influence of bagging on fruit maturity period, storage property, protection of plant disease, insect pets ,sunburn and prevention from residual effects of pesticides have also been described (Jing, 2011).

Hence, the objective of this work was to study the effect of some spray treatments with $\mathrm{GA}_{3}, \mathrm{CaCl}_{2}$, kaolin and bagging on fruit cracking, sunburn and quality of Manfaloty and Wonderful pomegranate cultivars. 


\section{MATERIALS AND METHODS}

This study was carried out during the two successive seasons of 2012 and 2013 on 5-years old Manfaloty trees and 3-years old Wonderful pomegranate trees, spaced at $3 \times 4 \mathrm{~m}$. under drip irrigation system grown in sandy soil in a private orchard located at El-Khatatba region, Menofia Governorate, Egypt. The trees were subjected to cultural practices which usually done in this orchard. The experiment was designed as a completely randomized block design within 8 treatments included 3 replicates, each replicate included two trees from each cultivar.

The applied treatments were arranged as follows:

1-Control (sprayed with water only)

2-Fruit bagging

3-Spraying of $\mathrm{GA}_{3}$ at $50 \mathrm{ppm}$

4- Spraying of $\mathrm{GA}_{3}$ at $100 \mathrm{ppm}$

5- Spraying of $\mathrm{CaCl}_{2}$ at $2 \%$

6- Spraying of $\mathrm{CaCl}_{2}$ at $4 \%$

7-Spraying of kaolin at 2.5\%

8- Spraying of kaolin at $5 \%$

Fruit bagging using paper bags $35 \times 30 \mathrm{~cm}, \mathrm{GA}_{3}$ and $\mathrm{CaCl}_{2}$ were sprayed at the second week of June, while kaolin was sprayed at three times one at the second week of June, July and August in both seasons.

At harvest time when fruits become fully colored (the first week of October for Manfaloty cv and third week of October for Wonderfull cv) in both seasons fruits per tree in each treatment was counted and fruit yield $(\mathrm{kg})$ per tree was calculated. Also percentage of fruit cracking, sunburn per tree and Marketable fruits were recorded as follow:

$$
\text { Fruit cracking } \%=\frac{\text { No.of cracked fruits }}{\text { Total NO.of fruits }} \times 100
$$

Sunburn $\%=\frac{\text { No.of sunburn fruits }}{\text { Total No.of fruits }} \times 100$

-Marketable fruits\%=Total N. of fruits - (No. of cracked+sunburn fruits) $\times 100$.

Fifteen normal fruits were taken from each treatment arise and transported to the laboratory of. Sakha Horticulture Research Station, Kafr ElSheikh Governorate for quality determination as follows.

1. Fruit weight $(\mathrm{g})$

2. Aril weight $(\mathrm{g})$ and percentage.

3. Peel weight $(\mathrm{g})$ and percentage.

4. Fruit length and diameter $(\mathrm{cm})$

5. Soluble solids content (SSC) percentage in fruit juice was determined by using hand refractometer.

6. Total acidity \% was determined according to A.O.A.C.(1995)

7.SSC/acid ratio in fruit juice

8. Vitamin C was determined according to A.O.A.C.(1995) 
9. Total anthocyanin in peel and juice of fruit was determined according to Ranganna (1979).

The obtained data were statistically analyzed using the analysis of variance (Snedecor \& Cochran, 1980), Treatment means were compared according to Duncan Multiple Range Test at 0.5 level of probability

\section{RESULTS AND DISCUSSION}

\section{The obtained results are discussed under the following: Yield and its components}

Regarding to Manfaloty pomegranate cv, data presented in Table (1) reveal that the highest fruits number /tree are obtained by spraying $\mathrm{CaCl}_{2} 4 \%$ and $\mathrm{GA}_{3}$ at100 ppm in the first season and second season respectively compared to the lowest one by control in both seasons. Trees sprayed with $\mathrm{GA}_{3}$ at $50 \mathrm{ppm}$ tended to increase fruit weight compared to the other treatments in both seasons. The trees treated with $\mathrm{GA}_{3}$ at $50 \mathrm{ppm}$ or 100 ppm, $\mathrm{CaCl}_{2}$ at $2 \%$ or $4 \%$ and Kaolin $5 \%$ gave the highest yield / tree without non-significant differences among them in the first season, meanwhile in the second one the $\mathrm{CaCl}_{2} 4 \%$ treatment resulted the highest yield compared to the lowest yield obtained by control.

As for the effect of treatments on Wonderful pomegranate cv the same table presented that the highest number of fruit /tree was obtained by $\mathrm{GA}_{3} 50$ ppm, $\mathrm{CaCl}_{2} 2 \%$ and kaolin $5 \%$ treatments without non-significant differences among them compared to the lowest one obtained by control in the first season while the highest fruit number / tree obtained by bagging treatment in the second season. $\mathrm{GA}_{3}$ at 50 or $100 \mathrm{ppm}, \mathrm{CaCl}_{2} 4 \%$, kaolin 2.5 or $5 \%$ and bagging treatment increased average fruit weight without nonsignificant differences among them over control in the first season. While the trees sprayed with $50 \mathrm{ppm} \mathrm{GA}$ gave the highest average fruit weight in the second season. Spraying the trees with $50 \mathrm{ppm} \mathrm{GA}$ tended to increase the yield over the other treatments in both seasons. The obtained results are in accordance with those of El-Khawaga( 2003), Singh et al. (2003), Mohamed (2004) on Manfaloty pomegranate cv. In addition Talaat et al. (2009) found that spraying $\mathrm{GA}_{3}$ at $100 \mathrm{ppm}$ increased fruit number and yield. Furthermore, Melgarejo et al. (2004), Abd El-Rhman (2010) and Samra \& Shalan (2013) mentiond that bagging or kaolin spraying increased fruit weight and yield $(\mathrm{kg}) /$ tree. Generally, increasing fruit yield and its component with spraying $\mathrm{GA}_{3}$ and $\mathrm{CaCl}_{2}$ may be due to the role of $\mathrm{GA}_{3}$ and $\mathrm{Ca}$ on fruit formation, abscission, cell elongation and fruit retention percentage (Aboutalebi \& Beharoznam, 2006). Also, $\mathrm{GA}_{3}$ may be due to increased concentration of photosynthesis in the shoot (Zoffoli et al., 2009).

From these results it is clear that, increasing the yield of Manfaloty trees than Wonderfull due to the different in trees age. Also, Manfaloty trees reached to fruiting age compared to Wonderfull trees which were still at the beginning of fruiting period. 
J. Plant Production, Mansoura Univ., Vol. 5 (5), May, 201

t 1 


\section{Fruit cracking and sunburn percentage:}

Data in Table (2) indicate that the differences among the treatments were highly significant as for the effect of treatments for two pomegranate cvs in both seasons the lowest percentage of fruit creaking obtained from bagging treatment followed by spraying with $\mathrm{CaCl}_{2}$ and $\mathrm{GA}_{3}$ treatment compared to the control. On the other hand, the control treatment gave the highest percentage of sunburnt fruits compared to the lowest percentages resulted by bagging treatment followed by kaolin $5 \%$ as for the tow pomegranate cvs in both seasons. In this respect Al- Hmadawi et al. (2011), Lal et al. (2012) and Abubakar et al. (2013) reported that spraying $\mathrm{GA}_{3}$ reduced fruit cracking in pomegranate fruits .Furthermore Melgarejo et al. (2004), Palitha et al. (2010) ,Ergun (2012), Hoda \& Hoda, (2013) and Samra \& Shalan (2013) reveal that bagging or kaolin application significantly reduced the severity of sunburn damage on pomegranate fruits. Generally, decreasing fruit cracking by bagging may be due to the effect of bagging on heat stress of fruit and water content of peel which decrease the transpiration from fruit surface (Glenn \& Puterka 2007). In addition, $\mathrm{GA}_{3}$ influence on fruit cracking indirectly by influencing of permeability or elasticity of the fruit cuticle (Sekse, 2005). Moreover $\mathrm{Ca}$ attributed to stabilization of membrane systems and the formation of calcium pectates and cell wall which increase rigidity of the middle portion and cell wall of the fruit (Jackman \& Stanly 1995). As for reducing sunburn damage by bagging and kaolin may be attributed to role of these treatments of reflecting radiation, especially UV wavelengths which reaching the surface of fruits (Ergun, 2012).

Table (2): Effect of $\mathrm{GA}_{3}, \mathrm{CaCl}_{2}$, kaolin and bagging treatments on percentage of fruit cracking and sunburn of Manfaloty and Wonderfull pomegranate cultivars.

\begin{tabular}{|l|c|c|c|c|c|c|c|c|}
\hline \multirow{3}{*}{ Treatments } & \multicolumn{4}{|c|}{ Manfaloty } & \multicolumn{4}{c|}{ Wonderfull } \\
\cline { 2 - 9 } & $\begin{array}{c}\text { Cracked fruits } \\
\%\end{array}$ & \multicolumn{2}{c|}{$\begin{array}{c}\text { Sunburned } \\
\text { fruit \% }\end{array}$} & $\begin{array}{c}\text { Cracked fruits } \\
\%\end{array}$ & $\begin{array}{c}\text { Sunburned fruit } \\
\%\end{array}$ \\
\cline { 2 - 9 } & 2012 & 2013 & 2012 & 2013 & 2012 & 2013 & 2012 & 2013 \\
\hline Control & $16.0 \mathrm{a}$ & $11.9 \mathrm{a}$ & $32.6 \mathrm{a}$ & $35.9 \mathrm{a}$ & $5.5 \mathrm{a}$ & $4.2 \mathrm{a}$ & $53.7 \mathrm{a}$ & $36.3 \mathrm{a}$ \\
\hline Bagging & $2.9 \mathrm{c}$ & $1.7 \mathrm{c}$ & $0.0 \mathrm{f}$ & $0.0 \mathrm{f}$ & $0.7 \mathrm{c}$ & $0.4 \mathrm{~b}$ & $0.0 \mathrm{f}$ & $0.0 \mathrm{~g}$ \\
\hline $\mathrm{GA}_{3}$ at $50 \mathrm{ppm}$ & $4.0 \mathrm{bc}$ & $2.6 \mathrm{bc}$ & $18.7 \mathrm{~b}$ & $17.5 \mathrm{c}$ & $1.4 \mathrm{c}$ & $2.6 \mathrm{a}$ & $26.2 \mathrm{~b}$ & $13.5 \mathrm{~d}$ \\
\hline $\mathrm{GA}_{3}$ at $100 \mathrm{ppm}$ & $2.6 \mathrm{c}$ & $2.9 \mathrm{bc}$ & $19.1 \mathrm{~b}$ & $26.5 \mathrm{~b}$ & $3.7 \mathrm{~b}$ & $3.3 \mathrm{a}$ & $25.2 \mathrm{bc}$ & $16.5 \mathrm{c}$ \\
\hline $\mathrm{CaCl}_{2}$ at $2 \%$ & $3.2 \mathrm{bc}$ & $2.4 \mathrm{bc}$ & $18.8 \mathrm{~b}$ & $15.2 \mathrm{~d}$ & $1.7 \mathrm{c}$ & $2.7 \mathrm{a}$ & $24.1 \mathrm{c}$ & $18.1 \mathrm{~b}$ \\
\hline $\mathrm{CaCl}_{2}$ at $4 \%$ & $3.2 \mathrm{bc}$ & $2.2 \mathrm{bc}$ & $14.0 \mathrm{c}$ & $17.7 \mathrm{c}$ & $2.3 \mathrm{bc}$ & $3.2 \mathrm{a}$ & $21.4 \mathrm{~d}$ & $17.9 \mathrm{~b}$ \\
\hline $\mathrm{Kaolin} 2.5 \%$ & $4.9 \mathrm{~b}$ & $2.8 \mathrm{bc}$ & $11.9 \mathrm{~d}$ & $14.4 \mathrm{~d}$ & $2.2 \mathrm{bc}$ & $3.8 \mathrm{a}$ & $17.2 \mathrm{e}$ & $8.9 \mathrm{e}$ \\
\hline $\mathrm{Kaolin} 5 \%$ & $4.2 \mathrm{bc}$ & $3.5 \mathrm{~b}$ & $8.6 \mathrm{e}$ & $10.8 \mathrm{e}$ & $1.8 \mathrm{c}$ & $2.8 \mathrm{a}$ & $16.6 \mathrm{be}$ & $6.2 \mathrm{f}$ \\
\hline $\mathrm{F}$. test at 0.05 & $\star \star$ & $\star \star$ & $\star *$ & $\star \star$ & $* \star$ & $\star \star$ & $* \star$ & $\star \star$ \\
\hline
\end{tabular}

Values within each column having different letters showed statistically significant differences $(p<0.05)$

\section{Marketable fruits percentage:}

Data in Table (3) demonstrate that, all treatments caused a highly significant increase in marketable fruits \% compared with the untreated trees (control) for the two cultivars. Furthermore bagging treatment gave the highest marketable percentage since it ranged about (97.09, 98.22 and 
99.22, 99.55) compared with the lowest percentage with obtained from the control ( 48.71, 47.88 and 40.72, 59.38) of Manfaloty and Wonderfull cvs respectively as 2012, 2013 seasons. These findings are agree with those reported by Wen Shuai (2009), Jing et al. (2009) ,Xiang et al. (2011) and Samra \& shalan (2013) on pomegranate fruits. Marketable fruits percentage increased as a result of decreasing fruit disorders (cracking and sunburn) percentages which were affected by all treatments compared with control.

Table (3): Effect of $\mathrm{GA}_{3}, \mathrm{CaCl}_{2}$, kaolin and bagging treatments on percentage of marketable and unmarketable fruits of Manfaloty and Wonderfull pomegranate cultivars.

\begin{tabular}{|c|c|c|c|c|c|c|c|c|}
\hline \multirow{3}{*}{ Treatments } & \multicolumn{4}{|c|}{ Manfaloty } & \multicolumn{4}{|c|}{$\begin{array}{l}\text { Wonderfull } \\
\end{array}$} \\
\hline & \multicolumn{2}{|c|}{$\begin{array}{l}\text { Marketable } \\
\text { fruits } \%\end{array}$} & \multicolumn{2}{|c|}{$\begin{array}{c}\text { Unmarketable } \\
\text { fruits } \%\end{array}$} & \multicolumn{2}{|c|}{$\begin{array}{c}\text { Marketable fruits } \\
\% \\
\end{array}$} & \multicolumn{2}{|c|}{$\begin{array}{c}\text { Unmarketable } \\
\text { fruits } \%\end{array}$} \\
\hline & 2012 & 2013 & 2012 & 2013 & 2012 & 2013 & 2012 & 2013 \\
\hline Control & $51.2 e$ & $52.1 \mathrm{f}$ & $48.7 a$ & $47.8 \mathrm{a}$ & $40.7 f$ & $59.3 f$ & $59.2 a$ & $40.6 a$ \\
\hline Bagging & $97.0 a$ & $98.2 a$ & $2.9 e$ & $1.7 f$ & $99.2 a$ & $99.5 a$ & $0.7 f$ & $0.4 f$ \\
\hline $\mathrm{GA}_{3}$ at $50 \mathrm{ppm}$ & $77.2 \mathrm{~d}$ & $79.8 d$ & $22.7 b$ & $20.1 c$ & $72.3 e$ & $83.8 \mathrm{~d}$ & $27.6 b$ & $16.1 \mathrm{c}$ \\
\hline $\mathrm{GA}_{3}$ at $100 \mathrm{ppm}$ & $78.1 d$ & $70.5 e$ & $21.8 b$ & $29.4 b$ & $70.9 \mathrm{e}$ & $80.1 \mathrm{be}$ & 29.0b & $19.8 b$ \\
\hline $\mathrm{CaCl}_{2}$ at $2 \%$ & $77.9 \mathrm{~d}$ & $82.3 c$ & $22.0 \mathrm{~b}$ & $17.6 \mathrm{~d}$ & $74.1 d$ & $79.0 \mathrm{e}$ & $25.8 c$ & $20.9 b$ \\
\hline $\mathrm{CaCl}_{2}$ at $4 \%$ & $82.6 c$ & $80.0 \mathrm{~d}$ & $17.3 \mathrm{bc}$ & $19.9 c$ & $76.2 c$ & $78.7 e$ & $23.7 d$ & $21.2 b$ \\
\hline Kaolin 2.5\% & $83.1 \mathrm{c}$ & $82.7 c$ & $16.9 \mathrm{bc}$ & $17.2 d$ & $80.4 b$ & $87.2 \mathrm{c}$ & $19.5 e$ & $12.7 d$ \\
\hline Kaolin 5\% & $87.1 b$ & $85 . b$ & $12.8 \mathrm{~d}$ & $14.4 \mathrm{e}$ & $81.5 b$ & $90.9 b$ & $18.4 \mathrm{e}$ & $9.1 \mathrm{e}$ \\
\hline F . test at 0.05 & ** & $\star *$ & ** & $\star \star$ & ** & ** & $\star \star *$ & $\star \star *$ \\
\hline
\end{tabular}

\section{Fruit length and diameter:}

Regarding to Manfaloty pomegranate cv data in Table (4) show that, there were non-significant differences among treatments as for fruit diameter in both seasons and for fruit length in the first season. Therefor the highest fruit length was obtained by $\mathrm{CaCl}_{2} 4 \%$ treatment followed by Kaolin $2.5 \%$ and $\mathrm{CaCl}_{2} 2 \%$ treatment without non-significant differences among them in the second season. In regard to Wonderfull cv the highest fruit length obtained by bagging and $\mathrm{GA}_{3} 50 \mathrm{ppm}$ compared to the lowest values recorded by control in both seasons respectively. Meanwhile bagging and $\mathrm{CaCl}_{2} 4 \%$ treatment gave the highest fruit diameter compared to control regarding with Wonderfull pomegranate cv. Also, Talaat et al. (2009), samra \& shalan (2013) on pomegranate and Abo El- Enien (2012) on Navel orange found that spraying $\mathrm{CaCl}_{2}$ or $\mathrm{GA}_{3}$ improvement fruit length and diameter. This can be attributed to $\mathrm{GA}_{3}$ wich stimulate cell elongation and membrane permeability to water uptake (Chaudhary et al. 2006) .Gibberellins are involved in cell division and cell elongation. They are known to influence fruit size (Zhang \&Whiting 2011) Gibberellic acid is also reported to promote growth by increasing plasticity of the cell wall followed by the hydrolysis of starch into sugars which reduces the cell water potential, resulting in the entry of water into the cell and causing elongation (Richard, 2006) . Furthermore, Melgarejio et al. (2004) mentioned that kaolin based an effective sunscreen while it gave non-significant differences for fruit diameter compared with untreated ones. 
Table (4): Effect of $\mathrm{GA}_{3}, \mathrm{CaCl}_{2}$, kaolin and bagging treatments on fruit length and fruit diameter of Manfaloty and Wonderfull pomegranate cultivars.

\begin{tabular}{|c|c|c|c|c|c|c|c|c|}
\hline \multirow{3}{*}{ Treatments } & \multicolumn{4}{|c|}{ Manfaloty } & \multicolumn{4}{|c|}{ Wonderfull } \\
\hline & \multicolumn{2}{|c|}{$\begin{array}{l}\text { Fruit length } \\
(\mathbf{c m})\end{array}$} & \multicolumn{2}{|c|}{$\begin{array}{l}\text { Fruit diameter } \\
\text { (cm) }\end{array}$} & \multicolumn{2}{|c|}{$\begin{array}{l}\text { Fruit length } \\
\text { (cm) }\end{array}$} & \multicolumn{2}{|c|}{$\begin{array}{l}\text { Fruit diameter } \\
\text { (cm) }\end{array}$} \\
\hline & 2012 & 2013 & 2012 & 2013 & 2012 & 2013 & 2012 & 2013 \\
\hline Control & 7.2 & $7.6 \mathrm{c}$ & 8.2 & 9.1 & $7.3 \mathrm{c}$ & $8.1 \mathrm{c}$ & $8.5 \mathrm{c}$ & 9.3 \\
\hline Bagging & 7.7 & $8.4 \mathrm{ab}$ & 8.8 & 9.9 & $8.0 \mathrm{a}$ & $8.1 \mathrm{bc}$ & $9.2 \mathrm{a}$ & 9.7 \\
\hline $\mathrm{GA}_{3}$ at $50 \mathrm{ppm}$ & 7.8 & $8.4 a b$ & 9.0 & 10.1 & $8.0 \mathrm{a}$ & $8.9 a$ & $8.6 \mathrm{bc}$ & 10.0 \\
\hline $\mathrm{GA}_{3}$ at $100 \mathrm{ppm}$ & 7.5 & $8.3 \mathrm{~b}$ & 8.7 & 9.6 & $8.0 \mathrm{a}$ & $8.5 \mathrm{ab}$ & $8.9 \mathrm{ab}$ & 10.1 \\
\hline $\mathrm{CaCl}_{2}$ at $2 \%$ & 7.8 & $8.6 \mathrm{ab}$ & 8.7 & 10.2 & $7.7 \mathrm{~b}$ & $8.5 \mathrm{ab}$ & $8.1 d$ & 9.9 \\
\hline $\mathrm{CaCl}_{2}$ at $4 \%$ & 7.6 & $8.8 \mathrm{a}$ & 8.7 & 10.0 & $7.8 \mathrm{ab}$ & $8.2 \mathrm{bc}$ & $9.2 \mathrm{a}$ & 9.7 \\
\hline Kaolin 2.5\% & 7.4 & $8.7 \mathrm{ab}$ & 8.4 & 10.1 & $7.8 \mathrm{ab}$ & $8.1 \mathrm{bc}$ & $8.9 a b$ & 9.7 \\
\hline Kaolin 5\% & 7.3 & $8.3 \mathrm{~b}$ & 8.5 & 9.9 & $8.0 \mathrm{a}$ & $8.1 \mathrm{bc}$ & $8.9 a b$ & 9.7 \\
\hline $\mathrm{F}$. test at 0.05 & Ns & $\star \star \star *$ & Ns & Ns & ** & ** & $\star \star *$ & Ns \\
\hline
\end{tabular}

Values within each column having different letters showed statistically significant differences $(p<0.05)$

\section{SSC \%, total acidity and SSC/acid ratio.}

It is clear from Table (5) that Manfaloty pomegranate trees sprayed with $50 \mathrm{ppm} \mathrm{GA}_{3}$ gave the highest parentage of SSC in the fruit juice followed by bagging treatment compared to the other treatments in both seasons. As for acidity and SSC /acid ratio there were no significant differences among treatments in the second season. Trees sprayed with $\mathrm{GA}_{3}$ at $100 \mathrm{ppm}$ gave the highest acidity followed by kaolin 2.5 or $5 \%$. Meanwhile the highest $\mathrm{SSC} /$ acid ratio was obtained by $\mathrm{CaCl}_{2} 2 \%$ or $4 \%$ compared to the lowest percentage obtained by $\mathrm{GA}_{3} 100 \mathrm{ppm}$ treatment.

With regard to Wonderfull pomegranate $\mathrm{cv}$ data in the same table reveal that kaolin 2.5 or $5 \%$ treatments increased SSC \% over all treatments in the first seasons followed by bagging and spraying by $\mathrm{GA}_{3} 50 \mathrm{ppm}$. Besides, the $\mathrm{GA}_{3} 50 \mathrm{ppm}, \mathrm{CaCl}_{2} 2 \%$ and control treatments gave the highest values in this respect compared to other treatments in the second season. All treatments increased acidity without non-significant differences among them compared to $\mathrm{CaCl}_{2} 2 \%$ treatment which gave the second rank in this respect in the first season. Meanwhile, bagging treatment gave the highest acidity compared to the lowest values obtained by $\mathrm{CaCl}_{2} 2 \%$ treatment in the second season. On the other hand $\mathrm{CaCl}_{2} 2 \%$ treatment increased SSC / acid ratio over the other treatments in both seasons. These results are in agreement with those reported by Talaat et al. (2009) and Abd El-Rhman (2010) on pomegranate mentioned that spraying $\mathrm{GA}_{3}$ and kaolin significantly increased soluble solids content (SSC). Furthermore, samra \& shalan (2013) and Xiang et al. (2011) stated that, bagging application increasing SSC and total acidity. Also, Ramezanian et al. (2009) revealed that, SSC increased by preharvest calcium sprays, but it was a slight difference between $\mathrm{CaCl}_{2} 2 \%$ and $4 \%$. The increase in total SSC in fruits with $\mathrm{Ca}$ or $\mathrm{GA}_{3}$ may be due to the effect of them in improving trees growth which include leaf area, total chlorophyll of the leaves, absorption of water, nutrition and increasing in food synthesized that translocated to fruits Al- Hmadawi et al.(2011). 
J. Plant Production, Mansoura Univ., Vol. 5 (5), May, 201 


\section{Total anthocyanin contents:}

Concerning anthocyanin (Juice and peel) data in Table (6) show that, for Manfaloty non-significant differences in juice anthocyanin content in the first season, while the differences were significant in the second one. The highest anthocyanin in Juice was obtained by bagging treatment compared to the lowest one produced by $\mathrm{GA}_{3}$ at $100 \mathrm{ppm}$ treatment. Other treatments gave intermediate values. The bagging treatment gave the highest anthocyanin in peel compared to the lowest values obtained by control and $\mathrm{CaCl}_{2} 4 \%$ in the first season, meanwhile in the second one all treatments increased anthocyanin content in peel without non-significant differences among them compared to control. With regard to Wonderfull pomegranate $\mathrm{cv}$, bagging treatment gave the highest juice and peel anthocyanin contents compared to the other treatments. In this respect Arakawa (1991), Jing et al. (2009), Xiang et al. (2011) and Samra \& shalan (2013) mentioned that the bagging pomegranate fruits with paper bags produced higher levels of anthocyanin. Generally, increasing anthocyanin contents by using bagging and kaolin may be due to the role of them for decrease the heat stress of fruit. In addition, Tora et al. (2008) presented that light exposure temperature is an important environmental factor that influences anthocyanin synthesis. Low temperature such as $25^{\circ} \mathrm{C}$ favors the anthocyanin biosynthesis, whereas high temperatures such as $35^{\circ} \mathrm{C}$ are associated with anthocyanin degradation and inhibition for anthocyanin accumulation. On the other hand, $\mathrm{GA}_{3}$ at $100 \mathrm{ppm}$ decreased anthocyanin content may be due to the role of $\mathrm{GA}_{3}$ on delaying the maturation and senescence of fruits (Yilmaz \& Özgüven, 2009).

From these results it is noticed that there were marked differences between two cultivars under study when compared to the results of the control, especially in the susceptibility to fruit cracking which was less percentage in Wonderfull cv compared with high percentage produced in Manfaloty. As well as acidity, anthocyanin content and coloring percentage of aril and peel. These differences may be due to genetic traits of the variety. The cracking may occur due to varietal characters and susceptibility (Kumar et al. 2009). In india, Malhotra et al. (1983) observed the least fruit splitting in Bedana and Dkolka pomegranate cvs. The varietal differences in cracking were attributed to skin structure and epidermal cell size. Yamamura \& Nation (1985) stated that, the more cracking resistance cultivars had significantly thicker cell wall and larger cells in subepidermal region than the other cultivars. On the other hand, the sunburn damage percentage of Wonderfull cv was higher in the first season as a result of the fact that the fruits were from young trees ( 3 years old) where the canopy was not fully developed exposing a high proportion of the fruit to full sun and high daily temperatures.

From this study, it is clear that bagging and spraying with $\mathrm{GA}_{3}, \mathrm{CaCl}_{2}$ and kaolin treatments increased Marketable fruits percentages, improved fruit quality, reduced fruit cracking and sunburn percentages of Manfaloty and Wonderfull pomegranate cultivars. Also, the best results were obtained by bagging, spraying with $\mathrm{GA}_{3}$ at $50 \mathrm{ppm}$ and kaolin at $5 \%$ in both cultivars with fruit yield and quality. Therefore, these treatments could be recommended for improving Manfaloty and Wonderfull pomegranate cvs performance under similar conditions. 
Table (6): Effect of $\mathrm{GA}_{3}, \mathrm{CaCl}_{2}$, kaolin and bagging treatments on ascorbic acid and acidity anthocyanin in juice and peel of Manfaloty and Wonderfull pomegranate cultivars.

\begin{tabular}{|c|c|c|c|c|c|c|c|c|}
\hline \multirow{4}{*}{ Treatments } & \multicolumn{4}{|c|}{ Manfaloty } & \multicolumn{4}{|c|}{ Wonderfull } \\
\hline & \multicolumn{4}{|c|}{ Anthocyanin $\mathrm{mg} / 100 \mathrm{ml}$} & \multicolumn{4}{|c|}{ Anthocyanin mg/100ml } \\
\hline & \multicolumn{2}{|c|}{ Juice } & \multicolumn{2}{|c|}{ Peel } & \multicolumn{2}{|c|}{ Juice } & \multicolumn{2}{|c|}{ Peel } \\
\hline & 2012 & 2013 & 2012 & 2013 & 2012 & 2013 & 2012 & 2013 \\
\hline Control & 18.4 & $16.0 \mathrm{c}$ & $14.8 \mathrm{c}$ & $15.4 b$ & 17.4 & $17.9 \mathrm{c}$ & 17.2ab & $18.6 a$ \\
\hline Bagging & 19.0 & $20.2 a$ & $18.0 \mathrm{a}$ & $18.7 \mathrm{a}$ & 17.8 & $20.8 \mathrm{a}$ & $17.9 a$ & $19.3 a$ \\
\hline $\mathrm{GA}_{3}$ at $50 \mathrm{ppm}$ & 18.8 & $19.6 a b$ & $16.7 a b$ & $18.4 a$ & 17.9 & 19.0ab & $16.9 \mathrm{~b}$ & $18.6 \mathrm{a}$ \\
\hline $\mathrm{GA}_{3}$ at $100 \mathrm{ppm}$ & 18.5 & $11.2 \mathrm{~d}$ & $16.1 \mathrm{bc}$ & $17.5 \mathrm{a}$ & 16.2 & $18.6 \mathrm{bc}$ & 17.3ab & $16.4 \mathrm{C}$ \\
\hline $\mathrm{CaCl}_{2}$ at $2 \%$ & 18.6 & $19.8 \mathrm{ab}$ & $16.9 \mathrm{ab}$ & $17.3 a$ & 17.3 & 19.3ab & $17.0 \mathrm{~b}$ & $18.6 \mathrm{a}$ \\
\hline $\mathrm{CaCl}_{2}$ at $4 \%$ & 18.6 & $16.9 \mathrm{bc}$ & $16.1 \mathrm{bc}$ & $17.3 \mathrm{a}$ & 16.7 & $19.8 a b$ & $16.0 \mathrm{c}$ & $17.5 \mathrm{~b}$ \\
\hline Kaolin 2.5\% & 18.9 & $18.7 \mathrm{bc}$ & $16.5 a b$ & $18.5 a$ & 17.9 & $19.2 \mathrm{ab}$ & $17.3 a b$ & $19.0 \mathrm{a}$ \\
\hline Kaolin 5\% & 18.8 & $17.4 a b$ & $16.7 a b$ & $18.7 \mathrm{a}$ & 17.5 & $17.8 \mathrm{c}$ & $17.4 a b$ & $19.3 a$ \\
\hline $\mathrm{F}$. test at 0.05 & Ns & ** & * & $* *$ & Ns & ${ }^{*}$ & ** & $* *$ \\
\hline
\end{tabular}

\section{REFERENCES}

A.O.A.C. (1995). Association of Official Analytical Chemists. Official Methods of Analysis. $15^{\text {th }}$ Ed. Washington D.C., USA.

Abd El-Rhman, I.E (2010). Physiological studies on cracking phenomena of Pomegranates. J. Appl. Sci. Res. 6 (6): 696-703.

Abo El-Enien, M.M.S. (2012). Improvement of Washington navel orange fruit quality using water regimes and GA3, potassium and calcium foliar applications. Ph.D. Thesis, Fac. Agric. Kafrelsheikh Univ., Egypt.

Aboutalebi, A. and B. Beharoznam (2006). Study on the effects of plant growth regulators on date fruit characteristics. International conference on date palm production and processing technology, book of abstracts.9-11 May 2006 - Muscat,Oman.

Abubakar, A. R.; N. Ashraf and M. Ashraf (2013). Effect of plant biostimulants on fruit cracking and quality attributes of pomegranate cv. Kandharikabuli. Academic journals. 8(44): 2171-2175.

Al- Hmadawi. A.M. , R.M. Al - Numani and W. H.AL - Shemmery (2011). Effect of pruning and spraying with $\mathrm{N}, \mathrm{Ca}$ and GA3 on some characters of fruits and percentage of cracking of fig cv. Asowd Diala. Euphrates J. Agric . Sci. Vol.(3)2:37-44.

Arakaw , O.(1991). Effect of temperature on anthocyanin accumulation in apple fruits as affected by cultivar, stage of fruit ripening and bagging.J. Hort. Sci.,66: $763-768$.

Byers, R.E., D.H. Carbaugh, and C.N. Presley (1990). 'Stayman' fruit cracking as affected by surfactants, plant growth regulators and other chemicals. J. Am. Soc. Hort. Sci. 115(3):405-411.

Chaudhary, B.R., M.D. Sharma, S.M. Shakya and D.M. Gautam, (2006). Effect of plant growth regulators on growth, yield and quality of chilly (Capsicum annuum L.) at Rampur, Chitwan. J. Inst. Agric. Anim. Sci., 27: 65-68. 
El-Khawaga, A.S. (2003). Effect of paclobutrazol and zinc sulphate on splitting and fruit quality of Improving Manfaloty pomegranate trees under Upper Egypt conditions . J. Agric. Sci. Mansoura. University,Egypt, 28(8) 6289-6294.

Ergun, M. (2012). Postharvest quality of galaxy apple fruit in response to kaolin-ased particle films application .J.Agric.Tech.,14: 599-607.

Glenn, D.M., G.J. Puterka, T., Vvonderzwet, R.E. Byer and C. Feldhake (1999). Hydrophobic particle films: a new paradigm for suppression of anthropoid pests and plant diseases. J. Econ. Entomol. 92: 759-771.

Jackman, R.L. and D.W. Stanley (1995). Perspectives in the textural evaluation of plant foods trends. Food Sci., 6: 187-194.

Jing, L., Q.Yang, L. Xiao-gang, B. Sheng, Z.Wang and Y.Chang (2009) Effect of microenvironment of bagging on appearance quality of 'Cuiguan' pears. J. Northwest A \& F University - Natural Science Edition 2009 Vol. (37) No. 10. pp. 133-139

Hoda, A. Khalil and Hoda, S.H. Aly (2013). Cracking and fruit quality of pomegranate (Punica granatum L.) as affected by pre-harvest sprays of some growth regulators and mineral nutrients. J. Horticult. Sci. Ornam. Plants 5(2) 71-76.

Kumar, R., P. Bakshi and J. N. Srivastava (2010). Fruit Cracking: A Challenging Problem of Fruit Industry. Krishi Sandesh.C.F. Abubakar, A. R.; N. Ashraf and M. Ashraf (2013) Effect of plant biostimulants on fruit cracking and quality attributes of pomegranate cv. Kandharikabuli. Academic journals. 8(44): 2171-2175.

Lal, S., N. Ahmed, J.I. Mir (2012). Effect of different chemicals on fruit cracking in pomegranate under karewa condition of Kashmir Valley. Indian J. Plant Physiol. 16 (3\&4) 326-330

Lansky, E.P. and R.A. Newman (2007). Review: Punica granatum (pomegranate) and its potential for prevention and treatment of inflammation and cancer. J. Ethnopharm., 109: 177-206.

Malhotra, V.K., H.N. Khajuria and J.S. Jawanda (1983). Studies on physicochemical characteristics of pomegranate cultivars. I: Physical characteristics. Punjab Hort. J., 23: 153-157

Melgarejo,P and Martinez, M .(1992). El Granado. Ed. Mundi-prensa, 163 pp. Melgarejo, P., J. J. Martínez, F.A. Hernández,, R. Martínez -Font, P. Barrows, and, A. Erez, (2004). Kaolin treatment toreduce pomegranate sunburn. Scientia Hort., 100: 349-353.

Mohamed , A.K.A (2004). Effect of gibberillic acid (GA3)and benzyladinine (BA) on spiting and quality of Manfaloty pomegranate fruits. J. Agri. Sci., 35(3) 11-21.

Palitha , W.J, M. Magdalena and J. Rogers (2010). The effect of maturity, sunburn and application of sunscreen on the internal and external qualities of pomegranate fruit grown in Australia. Scientia Hort, 124: 5761.

Ramezanian A., M. Rahemi and M. R.Vazifehshenas (2009). Effects of foliar application of calcium chloride and urea on quantitative and qualitative characteristics of pomegranate fruits. Scientia Horticulturae 121:171175 
Ranganna, S. (1979). Manual of analysis of fruit and vegeTable products. New Delhi India Tanta Mc Graw Hill Publishing Company. Limited Chapter 4: 77-83.

Richard, M.(2006). How to grow big peaches. Dep. Of Hort. Virginia Tech.Blacksburg,VA.24061.Internet,www.Rce.rutgers.edu. 8 pages, August. C.F. Abubakar, A. R.; N. Ashraf and M. Ashraf (2013) Effect of plant biostimulants on fruit cracking and quality attributes of pomegranate cv. Kandharikabuli. Academic journals. 8(44): 2171-2175.

Samra, B. N. and A. M. Shalan (2013). Studies on thinning, bagging and aluminum silicate spraying on yield and quality of Wonderfull pomegranate. J. Plant Production, Mansoura Univ., VOL.4 (2) 219227.

Schupp, J. R., E. Fallahi and I. J. Chun (2002). Effect of particle film on fruit sunburn, maturity and quality of "Fuji" and "Honeycrisp" apples. HortTechnology.12: 87-90.

Sekse, L., Bjerke, K.L and Vangdal, E. (2005). Fruit cracking in sweet cherries - An integrated approach. Acta. Hort. 667:471-474.

Sepahi, A. (1986) $\mathrm{GA}_{3}$ concentration for controlling fruit cracking in pomegranates. Iran Agric. Res., 5:93-99.

Sharma,S.B. and Dhillon, B.S. (1986). Endogenous level of gibberellins in relation to fruit cracking in litchi (Litchi chinensis Sonn). J. Res. Punjab Agric. Univ. 23:432-434.

Singh, D.B., B.D.Sharma and R.Bhargava (2003). Effect of boron and GA3 to control fruit cracking in pomegranate (Punica granatum) Current Agric., 27 (1/2): 125-127.

Snedecor, G.W. and W.G.Cochran, (1980). Statistical .Oxford State Univ., Press, lowa USA $6{ }^{\text {th }}$ edition.

Talaat K.R. EL-Mahdy; A.K.A. Mohamed and N. I. A. Mohamed (2009). Effect of flower thinning and spraying with gibberellic acid and ethephon on yield and fruit quality of Manfaloty pomegranate cultivar. Assuit J. of Agric. Sci., 40:69-91.

Tora, J.M., J. Lee, S. E. Spayd and C. E. Scagel (2008). Berry temperature and solar radition, proportion and concentration of anthocyanin in Merlot grapes. Amear. J. Enol. Vitic., 59: 235-247.

Tuckey, R. B.(1986). Calcium sprays for sweet cherries. Proc. Wash. State Hort. Assoc., 79: 194-198.

Wen Shuai (2009). Application of techniques on citrus bagging. Cuhure Academic. Periodical of Farm Products Processing. ( 7 ) :62

Xiang, L.I , M.A. Jian-zhong,S. Yun-dong, Z. Qing and Z. Xin-ming (2011).Effect of type of bagging on quality and safety of pomegranate. J. Beijing Tech. and Business Univ.(Natural Science Edition): 2011-05

Yamamura, H. and R. Naito (1985). Susceptibility to berry splitting in several grape cultivars .J. Japan Soc. Hort. Sci. 53 (4): 390 - 395.

Yilmaz, C. and A.I. Özgüven (2009). The effects of some plant nutrients, gibberellic acid and pinolene treatments on the yield, fruit quality and cracking in pomegranate. Acta Hort. (ISHS) 818:205-212 
Zhang, C. and M.D. Whiting (2011). Improving 'Bing'sweet cherry fruit quality with plant growth regulators. Scientia Hort., 127: 341-346.

Zoffoli, J.P., B.A. Latorre and P. Naranjo (2009). preharvest application of growth regulators and their effect on postharvest quality of Table grapes during cold storage. Post-Harvest Bio. and Tech. 51:183-192

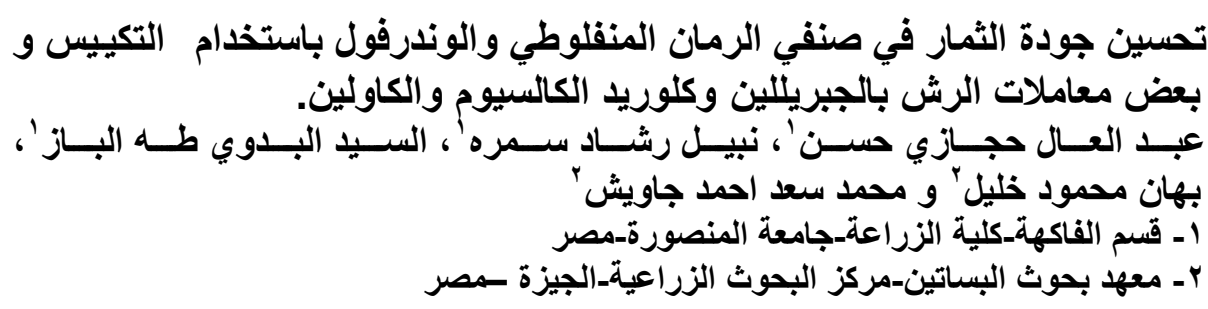

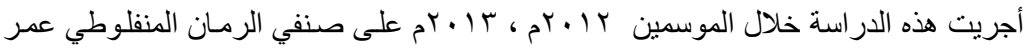

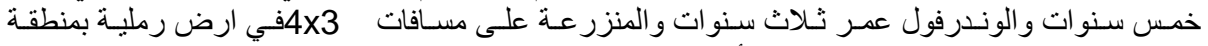

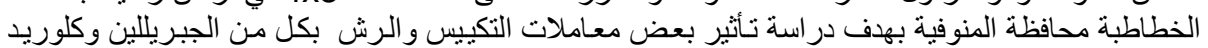

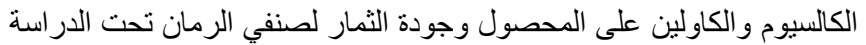

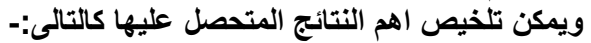

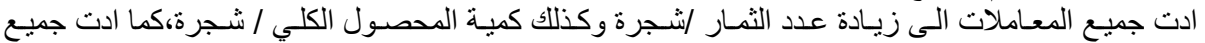

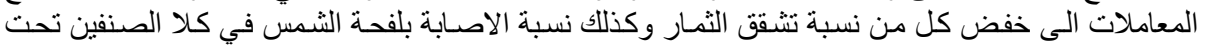

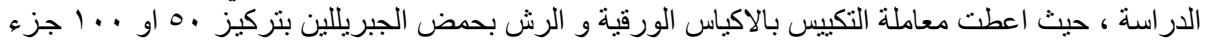

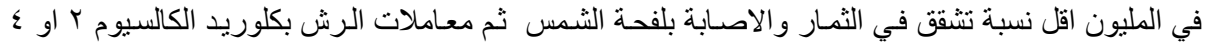

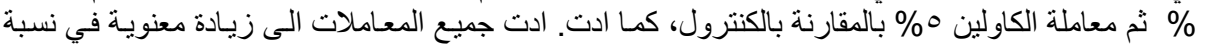

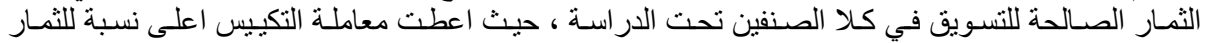

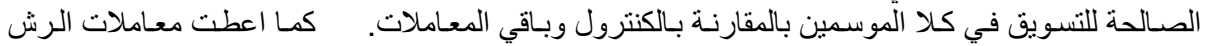

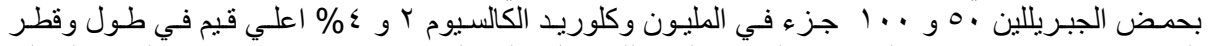

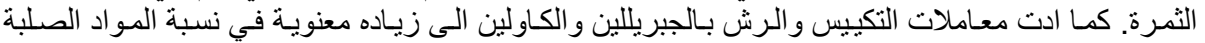

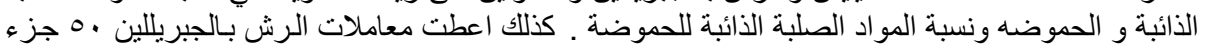

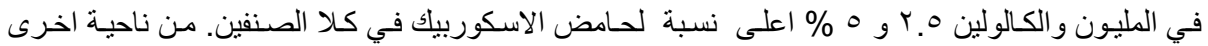

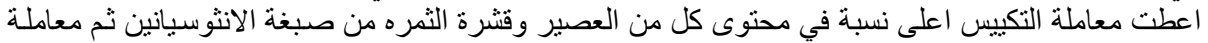

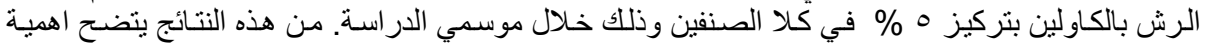

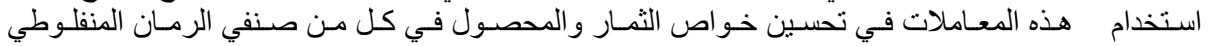

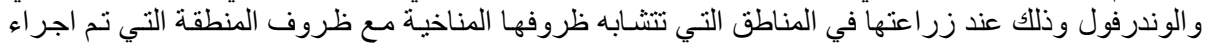

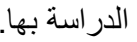


Table (1): Effect of $\mathrm{GA}_{3}, \mathrm{CaCl}_{2}$, kaolin and bagging treatments on number of fruit /tree, average of fruit weight of Manfaloty and Wonderfull pomegranate cultivars.

\begin{tabular}{|c|c|c|c|c|c|c|c|c|c|c|c|c|}
\hline \multirow{3}{*}{ Treatments } & \multicolumn{6}{|c|}{ Manfaloty } & \multicolumn{6}{|c|}{ Wonderfull } \\
\hline & \multicolumn{2}{|c|}{$\begin{array}{c}\text { No .of } \\
\text { fruit/tree }\end{array}$} & \multicolumn{2}{|c|}{$\begin{array}{l}\text { Average fruit } \\
\text { weight(g) }\end{array}$} & \multicolumn{2}{|c|}{$\begin{array}{c}\text { Yield } \\
(\mathrm{kg}) / \text { tree }\end{array}$} & \multicolumn{2}{|c|}{$\begin{array}{c}\text { No .of } \\
\text { fruit/tree }\end{array}$} & \multicolumn{2}{|c|}{$\begin{array}{c}\text { Average fruit } \\
\text { weight(g) }\end{array}$} & \multicolumn{2}{|c|}{$\begin{array}{c}\text { Yield } \\
\text { (kg)/tree }\end{array}$} \\
\hline & 2012 & 2013 & 2012 & 2013 & 2012 & 2013 & 2012 & 2013 & 2012 & 2013 & 2012 & 2013 \\
\hline Control & $51.1 \mathrm{~h}$ & $40.8 f$ & $269.4 b$ & $365.0 d$ & $13.7 c$ & $14.9 d$ & $25.0 d$ & $31.5 e$ & $304.5 b$ & $376.0 \mathrm{c}$ & $7.6 \mathrm{c}$ & $11.8 c$ \\
\hline Bagging & $61.1 \mathrm{~g}$ & $44.3 e$ & $329.4 a b$ & $476.0 \mathrm{~b}$ & $20.2 b$ & $20.9 c$ & $32.8 a b$ & $44.0 \mathrm{a}$ & $355.2 a$ & 420.4bc & $11.7 \mathrm{ab}$ & $18.4 \mathrm{a}$ \\
\hline $\mathrm{GA}_{3}$ at $50 \mathrm{ppm}$ & $66.8 d$ & $44.5 e$ & $372.8 a$ & $488.00 a$ & $21.6 a$ & $21.7 b c$ & $38.8 a$ & $31.5 e$ & $348.6 a$ & $496.0 a$ & $13.5 a$ & $15.6 a$ \\
\hline $\mathrm{GA}_{3}$ at $100 \mathrm{ppm}$ & $65.8 \mathrm{a}$ & $53.1 \mathrm{a}$ & 332.0ab & $442.5 c$ & $21.9 a$ & 23.5ab & $31.3 c$ & $34.0 d$ & $354.5 a$ & 464.0ab & $11.2 b$ & $15.8 b$ \\
\hline $\mathrm{CaCl}_{2}$ at $2 \%$ & $65.0 e$ & $50.0 c$ & 328.7ab & $479.8 a b$ & $21.4 a$ & $20.6 c$ & $38.5 a$ & $36.6 c$ & $306.6 b$ & 438.3ab & $11.8 a b$ & 16.0ab \\
\hline $\mathrm{CaCl}_{2}$ at $4 \%$ & $72.8 b$ & $44.8 \mathrm{e}$ & $314.2 a b$ & 482.0ab & $22.6 a$ & $24.0 a$ & $32.3 b c$ & $37.6 c$ & $356.6 a$ & $413.6 b c$ & $11.5 a b$ & $15.3 b$ \\
\hline Kaolin 2.5\% & $61.6 f$ & $46.5 d$ & $283.9 b$ & $473.0 \mathrm{~b}$ & $17.5 b$ & $21.2 c$ & $37.5 a$ & $41.8 b$ & $352.5 a$ & $392.5 b c$ & 12.9ab & $16.4 \mathrm{ab}$ \\
\hline Kaolin 5\% & $70.6 c$ & $51.5 b$ & $306.8 b$ & $444.3 c$ & $21.6 a$ & $20.6 c$ & $37.8 a$ & $41.0 b$ & $343.0 a$ & $420.2 b c$ & 13.3ab & $17.2 \mathrm{ab}$ \\
\hline $\mathrm{F}$. test at 0.05 & $\star *$ & ** & ** & $\star *$ & $\star * *$ & $\star \star *$ & ** & ** & * & * & ** & ** \\
\hline
\end{tabular}

Values within each column having different letters showed statistically significant differences $(p<0.05)$ 
Table (5): Effect of $\mathrm{GA}_{3}, \mathrm{CaCl}_{2}$, kaolin and bagging treatments on SSC\%, acidity and SSC/ acid ratio of Manfaloty and Wonderfull pomegranate cultivars.

\begin{tabular}{|c|c|c|c|c|c|c|c|c|c|c|c|c|}
\hline \multirow{3}{*}{ Treatments } & \multicolumn{6}{|c|}{ Manfaloty } & \multicolumn{6}{|c|}{ Wonderfull } \\
\hline & \multicolumn{2}{|c|}{$\begin{array}{c}\text { SSC } \\
\% \\
\end{array}$} & \multicolumn{2}{|c|}{$\begin{array}{c}\text { Acidity } \\
\%\end{array}$} & \multicolumn{2}{|c|}{$\begin{array}{l}\text { SSC / Acid } \\
\text { ratio }\end{array}$} & \multicolumn{2}{|c|}{$\begin{array}{c}\text { SSC } \\
\% \\
\end{array}$} & \multicolumn{2}{|c|}{$\begin{array}{c}\text { Acidity } \\
\% \\
\end{array}$} & \multicolumn{2}{|c|}{$\begin{array}{c}\text { SSC/ } \\
\text { Acid ratio }\end{array}$} \\
\hline & 2012 & 2013 & 2012 & 2013 & 2012 & 2013 & 2012 & 2013 & 2012 & 2013 & 2012 & 2013 \\
\hline Control & 15.7 & $14.9 \mathrm{c}$ & $1.08 \mathrm{~b}$ & 1.10 & 15.0ab & 14.2 & $14.9 \mathrm{~b}$ & $16.5 a$ & $1.30 \mathrm{a}$ & $1.17 \mathrm{~b}$ & $11.4 \mathrm{bc}$ & $14.1 \mathrm{~b}$ \\
\hline Bagging & 16.3 & 16.3ab & $1.09 b$ & 0.96 & $14.8 \mathrm{ab}$ & 17.4 & $15.8 \mathrm{ab}$ & 15.7ab & $1.43 a$ & $1.48 \mathrm{a}$ & $11.0 \mathrm{c}$ & $10.6 c$ \\
\hline $\mathrm{GA}_{3}$ at $50 \mathrm{ppm}$ & 16.0 & $16.9 a$ & $1.06 \mathrm{~b}$ & 0.89 & $15.1 \mathrm{ab}$ & 19.6 & $15.8 a b$ & $16.7 a$ & $1.30 \mathrm{a}$ & $1.21 \mathrm{ab}$ & $12.1 \mathrm{bc}$ & $14.0 \mathrm{~b}$ \\
\hline $\mathrm{GA}_{3}$ at $100 \mathrm{ppm}$ & 15.9 & $15.2 c$ & $1.41 \mathrm{a}$ & 1.09 & $10.9 c$ & 14.0 & 15.6ab & $14.7 b$ & $1.44 a$ & $1.11 \mathrm{bc}$ & $10.8 c$ & $13.1 \mathrm{bc}$ \\
\hline $\mathrm{CaCl}_{2}$ at $2 \%$ & 15.7 & $15.3 b c$ & $0.97 b$ & 0.74 & $16.4 a$ & 20.8 & $15.1 b$ & $16.6 \mathrm{a}$ & $0.70 \mathrm{~b}$ & $0.88 c$ & $19.2 a$ & $19.1 \mathrm{a}$ \\
\hline $\mathrm{CaCl}_{2}$ at $4 \%$ & 16.5 & $14.6 \mathrm{c}$ & $0.98 b$ & 1.17 & $16.9 a$ & 12.5 & $15.6 a b$ & $15.6 a b$ & $1.18 \mathrm{a}$ & $1.34 a b$ & $13.8 \mathrm{bc}$ & $11.9 \mathrm{bc}$ \\
\hline Kaolin 2.5\% & 16.3 & $14.6 c$ & $1.26 a b$ & 0.91 & $12.9 b c$ & 16.1 & $16.7 a$ & 15.6ab & $1.35 a$ & $1.10 \mathrm{bc}$ & $12.4 \mathrm{bc}$ & $14.2 b$ \\
\hline Kaolin 5\% & 15.1 & $15.0 \mathrm{c}$ & $1.16 a b$ & 0.82 & 13.5ab & 19.1 & $16.5 a$ & $15.7 a b$ & $1.11 \mathrm{a}$ & $1.14 \mathrm{bc}$ & $15.4 a b$ & $14.0 \mathrm{~b}$ \\
\hline $\mathrm{F}$. test at 0.05 & Ns & ** & * & Ns & * & Ns & * & * & * & * & * & ** \\
\hline
\end{tabular}

Values within each column having different letters showed statistically significant differences $(p<0.05)$ 